\title{
Maxillary implant-supported fixed prosthesis engaged by distal-extension removable partial denture for 10 years: a case report
}

\author{
Ri Ryu1, Yeon-Hee Park', Won-suk Oh², Jung-Jin Lee ${ }^{1,3}$, Ju-mi Park ${ }^{1,3 *}$ \\ ${ }^{1}$ Department of Prosthodontics, School of Dentistry and Institute of Oral Bio-Science, Jeonbuk National University, Jeonju, \\ Republic of Korea \\ ${ }^{2}$ Department of Biologic and Materials Sciences \& Prosthodontics, University of Michigan School of Dentistry, Ann Arbor, \\ Michigan, USA \\ ${ }^{3}$ Research Institute of Clinical Medicine of Jeonbuk National University-Biomedical Research Institute of Jeonbuk National \\ University Hospital, Jeonju, Republic of Korea
}

Prosthodontic decision and management should be considered the patient's aesthetic need for anterior teeth in maxillary edentulism. This case report describes 10-year clinical outcome of a maxillary edentulous patient was rehabilitated by means of an implant-supported fixed dental prosthesis (ISFDP) for the anterior region and a distal-extension removable partial denture (RPD) for the posterior region. The ISFDP was designed to splint 4 endosseous implants as one unit and engaged by the RPD. The edentulous mandible was restored by means of an implant-supported overdenture. Over the course, no major adverse event occurred other than wear, discoloration, and breakage of resin veneers and artificial teeth. (J Dent Rehabil Appl Sci 2020;36(2):121-7)

Key words: edentulism, implant supported dental prosthesis; removable partial denture; dental implant; complication

\section{Introdcution}

A common prosthodontic treatment of an edentulous maxilla includes a conventional complete denture (CD) or an implant-supported overdenture (IOD). ${ }^{1-4}$ These treatment options are useful when the patient has excessive ridge resorption and unusual maxillomandibular relationship. However, these prostheses need to be removed from the mouth for recovery of the tissue and maintenance of oral health..$^{5-7}$ Some patients may be compliant to these requirements because of discomfort with no teeth in their mouth, especially maxillary anterior teeth. ${ }^{8,9}$

\footnotetext{
*Correspondence to: Ju-mi Park

Professor, Department of Prosthodontics, Institute of Oral Bio-Science, School

of Dentistry, Jeonbuk National University and Research Institute of Clinical Medicine of Jeonbuk National University-Biomedical Research Institute of Jeonbuk National University Hospital, 20, Geonji-ro, Deokjin-gu, Jeonju, 54907, Republic of Korea

Tel: +82-63-250-2118, Fax: +82-63-250-2218, E-mail: jmpark@jbnu.ac.kr

Received: April 20, 2020/Last Revision: May 7, 2020/Accepted: May 25, 2020
}

The patient's comfort and oral function can be restored by means of an implant-supported fixed complete denture (ISFCD). ${ }^{1,10}$ However, the ISFCD has limitation to patients who present with deficient bone quantity on posterior region and systemic condition excluding placement of multiple implants. ${ }^{1,4}$ Alternatively, the combination of fixed and removable prosthesis can be considered. The anterior segment can be restored with an implant-supported fixed dental prosthesis (ISFDP) and the posterior segment with of a conventional removable partial denture (RPD). ${ }^{8,911-13}$ However, there is a concern with regard to potential stress accumulation on the

Copyright $(2020$ The Korean Academy of Stomatognathic Function and Occlusion. (c) It is identical to Creative Commons Non-Commercial License. 
implants supporting the ISFDP and being engaged by an RPD. ${ }^{14-17}$ Yet, no long-term study is available with this type of treatment modality.

This case report describes 10 -yr clinical outcome of a patient whose edentulous maxilla was restored by means of an ISFDP in the anterior segment and a distal-extension RPD in the posterior segment. The ISFDP was designed to splint 4 endosseous implants as one unit and engaged by the RPD. The edentulous mandible was restored by means of an implantsupported overdenture.

\section{Case Report}

A 68-yr-old edentulous woman visited and expressed dissatisfaction with her existing conventional CDs. She wanted an ISFDP for her maxillary anterior teeth. Her edentulous mandible was severely atrophic. Her medical history was unremarkable. In 2008, the patient's edentulous maxilla was restored by means of an ISFDP for the anterior segment and a distal-extension RPD for the posterior segment. Her edentulous mandible was restored by means of a mandibular IOD. ${ }^{13}$

A total of 8 endosseous regular-neck dental implants (Standard Implant, Straumann, Basel, Switzerland) were placed: 4 in the maxilla and 4 in the mandible. The maxillary implants were placed for supporting the ISFDP in anterior to the maxillary sinus. The custom abutment was fabricated with precious metal (Dental Casting Gold Alloy, Heesung catalysis, Cheongju, Korea). The metal framework of ISFDP was fabricated with casting using a nickelchrome-cobalt alloy (T-3 C\&B Alloy, CMP Industries, New York, USA). The artificial denture teeth (Endura Anterio A3, Shofu Dental Corp, Kyoto, Japan) were arranged and the gingiva was veneered with self-cure acrylic resin (Vertex SC, Vertex Dental, Zeist, The Netherlands). The ISFDP was designed to demonstrate screw access holes on the occlusal surface and was luted intraorally to abutments. Although the prosthesis was cemented to the abutments, the ISFDP was retained with screw to the fixture.

The RPD was designed to engage the ISFDP by means of direct and indirect retainers. Occlusal rests were placed directly over supra-structure of implants, and 19-gauge base metal alloy wrought wire retentive clasp arms were contoured to engage 0.01 -inch mesiofacial undercuts. A modified palatal strap was chosen as the major connector to obtain additional support and stability from the palate. The implant fixtures of lower arch were connected by an implant connecting bar (Dental Casting Gold Alloy, Heesung catalysis). An mandibular IOD was constructed to engage the bar by means of attachment elements: Hader bar segment (Hader-EDS Bar System, Attachments International, California, USA) between right and left lateral incisor and right and left first premolar and extra-coronal resilient attachments (ERA Attachment, Sterngold Dental, Attleboro, USA) at each end of bar. The teeth were arranged to centralize the masticatory forces with lingualized occlusal scheme. The anterior guidance was controlled to reduce lever action exerted on ISFDP (Fig. 1).
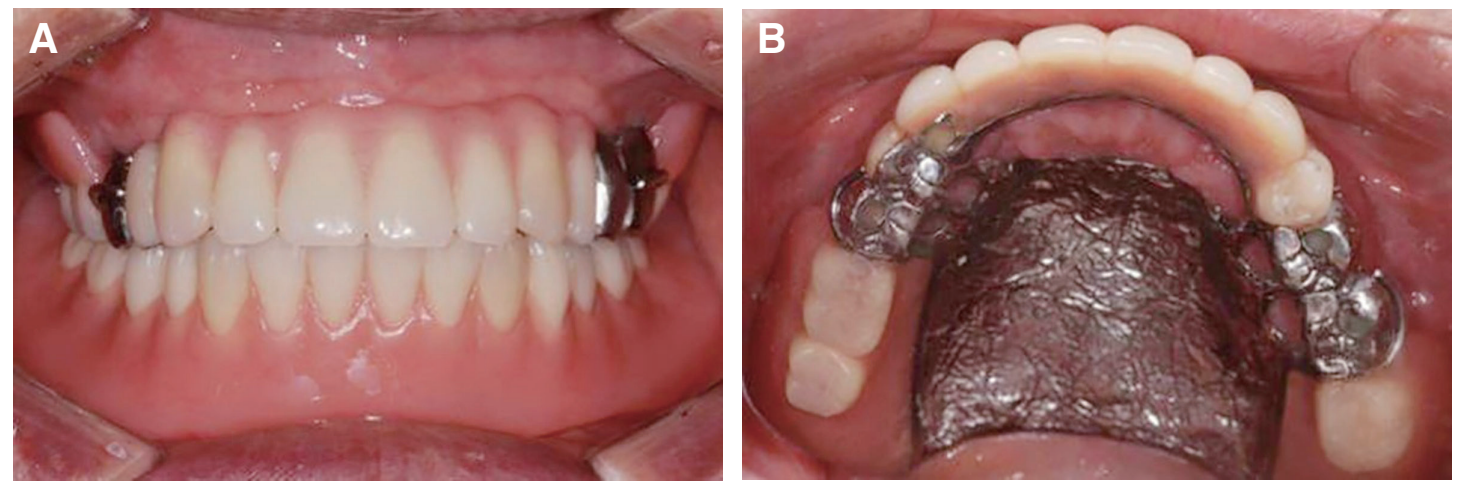

Fig. 1. (A) Maxillary implant-supported fixed partial denture and removable partial denture opposing mandibular implant overdenture placed, (B) Four occlusal rests were placed on premolar and molar. Ninety-gauge wrought wire retentive clasps were engaged 0.01-inch undercut. Major connector was modified palatal strap. 
The patient was recalled every 3 - 6 months after placement of the maxillary and mandibular prostheses. At each follow-up appointment, the patient was provided oral hygiene instructions with oral prophylactic procedures. The removable prostheses were cleaned in an ultrasonic cleaner. Clinical examination and radiographic survey were followed to evaluate stability of the ISFDP and health of the peri-implant mucosa. At 1-yr follow-up, the patient complained of decreased retention of the maxillary RPD. The wire clasps were adjusted using a plier, to engage the undercuts and demonstrate a passivity at rest.

The patient was compliant to instructions and did not demonstrate any signs or symptoms of implant failure for 30-mo follow-up period except for breakage of resin veneer layered on the right maxillary canine (Fig. 2). The ISFDP was removed from the

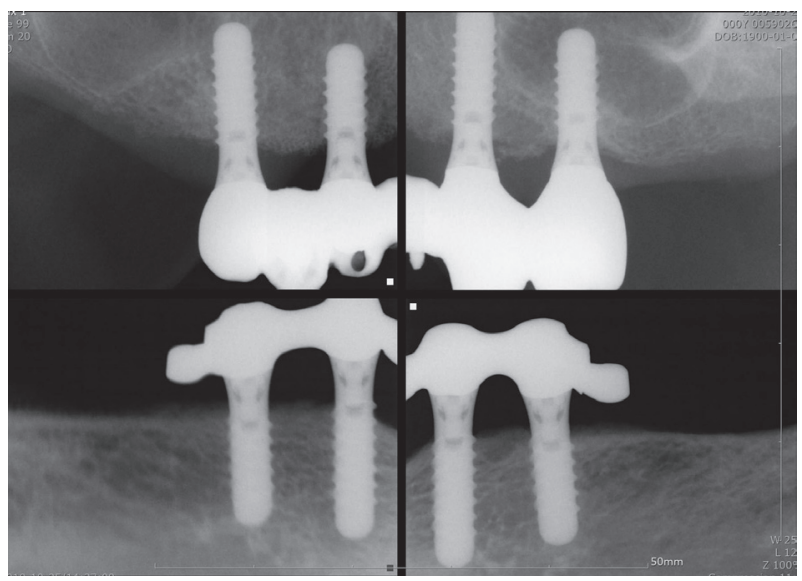

Fig. 2. No pathologic sign was shown in postoperative periapical radiographs after 30 months. mouth with the abutments for repair. The abutments were unscrewed from the implant fixtures through the screw access holes built in the ISFDP. The healing abutments were connected to the implants to prevent collapse of the peri-implant mucosa. The ISFDP was repaired with an acrylic resin (Vertex SC, Vertex Dental) and screwed to the fixtures up to 35 $\mathrm{Ncm}$ using a torque rachet (Straumann). The screw access holes were filled with silicone material (EZ seal, Megagen, Daegu, Korea) and composite resin (Filtek Z350 XT, 3M ESPE, Minnesota, USA). During the course of 4-yr follow-up, there were no negative signs or symptoms related to the prosthodontic treatment, except for dislodgement of one of resins placed in the screw access holes.

Eight and half years later, the ISFDP sustained breakage of resin veneers layered on the right central and lateral incisors, and the right lateral incisor of the mandibular IOD broke at the incisal level (Fig. 3A). The patient indicated she had lost her balance and fell on floor, inflicting facial injuries and breakage of artificial teeth. The prostheses were otherwise stable with no signs of screw loosening or breakage. The ISFDP was retrieved from the mouth and was returned to the mouth after the broken teeth were repaired with an acrylic resin (Vertex SC, Vertex Dental) (Fig. 3B).

During 10-yr follow-up period, the implants had kept stability with minimal loss of crestal bone (Fig. 4A). The peri-implant mucosa was healthy with maintaining attached gingival cuff, although a mild inflammatory reaction was noted around the maxillary left implants (Fig. 4B). Throughout the follow-
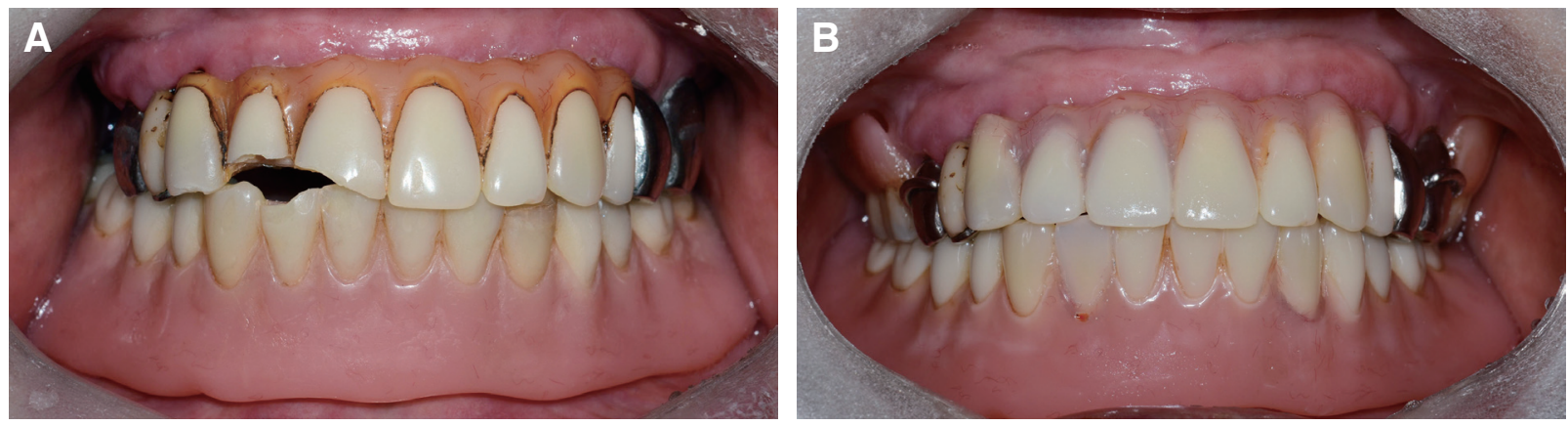

Fig. 3. (A) Breakage of artificial teeth by accident and discoloration of acrylic veneer resin were shown, (B) Prostheses were repaired extraorally and placed. 

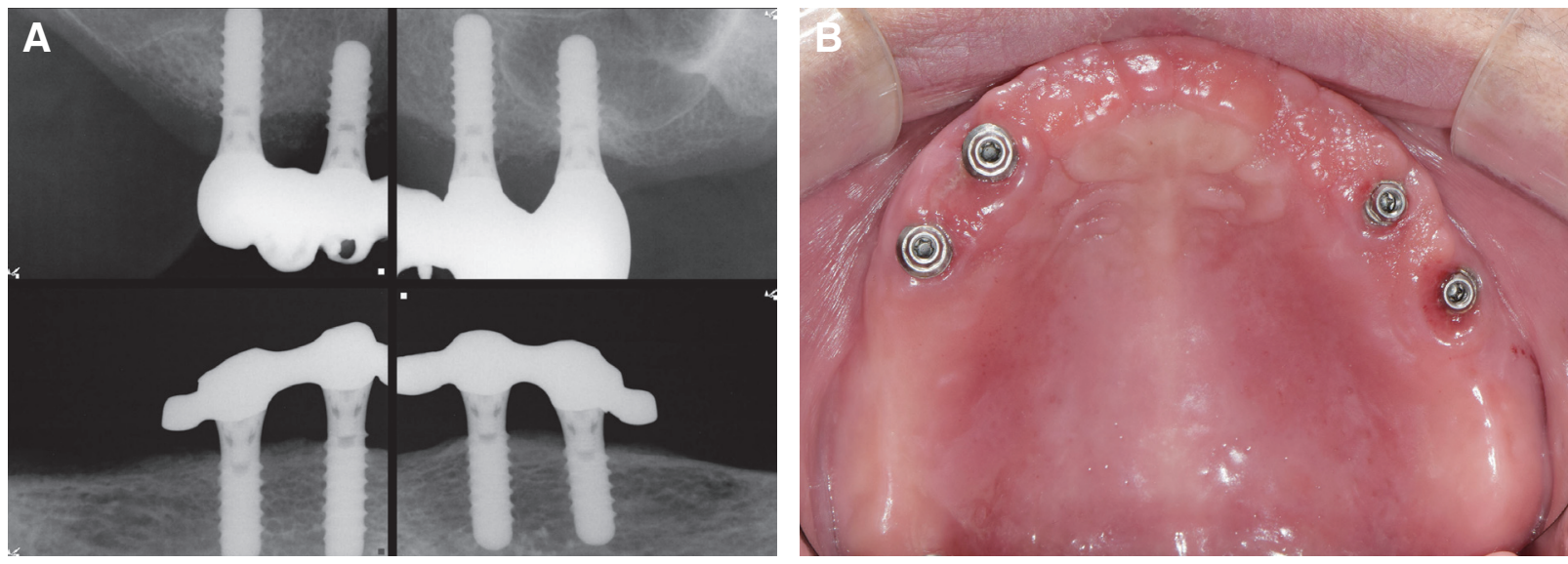

Fig. 4. (A) Ten-yr postoperative periapical radiographs revealing stable implants with minimal bone loss, (B) Occlusal view of edentulous maxilla demonstrating minimal tissue reaction around the implant.

up period, the IOD kept. No negative event occurred with the mandibular IOD other than replacement of nylon retention inserts of the attachment element. The patient was regularly followed and instructed to use interproximal brush and oral irrigator to keep oral hygiene, especially underneath the implant connecting bar and ISFDP. At 10-yr follow-up appointment, the ISFDP showed a discoloration and wear of acrylic resin.

\section{Discussion}

The anterior ISFDP has rest seats, guide planes, and undercuts to receive a distal-extension base RPD. ${ }^{11-13}$ Upon occlusal loading, the maxillary ISFDP may receive high forces driven from the RPD. ${ }^{15}$ These forces can be significant to cause biological and/or mechanical complications of the implant because of an leverage action from clasp assembly of the RPD. ${ }^{4,15-17}$

To reduce the risk of complications, the ISFDP was designed to splint the maxillary implants, and the RPD embraced a stress releasing concept with using mesial rests and 19-gauge wrought wire clasp arms. ${ }^{4,13}$ The RPD framework was designed to engage broad surface of the palate and tuberosity and fitted through the process of physiologic adjustment. ${ }^{13,14}$ The occlusal rest was designed to seat di- rectly over implant support and adjusted to control the rotational movement of the RPD. ${ }^{14}$

The patient was followed regularly to evaluate oral hygiene and assess stability of the prostheses. ${ }^{5-7}$ The peri-implant mucosa appeared unremarkable with minimal inflammatory reaction. The importance of oral hygiene was emphasized at each visit to keep stability of implant support. Over the course, the ISFDP was retrieved twice to repair broken veneers of acrylic resin. The RPD kept functional stability without a need of lining of the base, although the wire clap arms were adjusted as needed to enhance the retention.

The ISFDP was luted to the abutments in the mouth to ensure a passive fit. ${ }^{16,17}$ This prosthesis was also retrievable because of the screw connection of the abutments to the fixtures. ${ }^{11-13}$ The abutments were individually screwed to each implant, and then the implants were splinted across the arch with metal framework of ISFDP. The ISFDP was designed to demonstrate screw access holes on the occlusal surface. The majority of excess luting agent was extruded through the holes. This effect of venting was advantageous in minimizing the residual cement around the margin of the ISFDP and avoiding potential development of peri-implantitis associated with cement remnants. ${ }^{4,18}$ The substructure of the ISFDP was cast in a base metal alloy to reduce the cost, although 
the abutments were cast in a high noble alloy. ${ }^{11-13} \mathrm{No}$ adverse reaction was noted with the combination of noble alloy abutments and base metal alloy prosthesis.

The antagonist may play an important role for prosthodontic success. ${ }^{2-4}$ The edentulous mandible was restored with an IOD. No mechanical complications were noted both in the maxillary and mandibular prostheses. There may be a cushioning effect through the resiliency of IOD attachments and mucosa of the posterior edentulous ridge of the mandible. .13,19 $^{2}$

Implant overdenture (IOD), compared to ISFDP in patients with edentulism who have severe alveolar bone resorption but do not want extensive surgery, can be an alternative treatment option that can reduce costs while meeting the patient's aesthetic and functional needs. ${ }^{20}$ Also, it is favorable to maintain oral hygiene. However, when the denture is removed, the patient can be dissatisfied with the absence of anterior teeth.

For aesthetic reasons, the patient wanted the teeth to remain even after the prosthesis was removed. As in this case report, the method of restoring the anterior teeth with the ISFDP and posterior teeth with the posterior-extended RPD can maintain the aesthetics of the patient and provide psychological satisfaction because the anterior teeth remain even after the denture is removed.

The patient expressed high satisfaction with the combination of fixed and removable prosthodontic treatments, especially with the capacity of retaining her maxillary anterior teeth at night. No major issue was noted with these prostheses over the course of 10 -yr follow-up. The maintenance was minimal for repair of acrylic veneer and replacement of resin teeth and nylon retention inserts of attachment elements. However, patient selection and compliance can be crucial for success of this type of treatment and avoid consequences associated with parafunctional activities. ${ }^{21}$

\section{Conclusion}

A patient with complete edentulism can be treated with the combination of fixed and removable pros- theses. Maxilla was restored with an ISFDP in the anterior region and a distal-extension RPD in the posterior region. Mandible was restored with an IOD. The ISFDP was engaged by means of the RPD and opposed the IOD. During 10-yr follow-up period, no severe mechanical and biological complications occurred except the discoloration of resin veneers and artificial teeth. The implants were maintained stable state. The patient expressed high satisfaction with the capacity of retaining the maxillary anterior teeth in her mouth at night.

\section{ORCID}

Ri Ryu https://orcid.org/0000-0002-6356-9400

Yeon-Hee Park https://orcid.org/0000-0002-9183-9244

Won-suk Oh https://orcid.org/0000-0002-2868-9490

Jung-Jin Lee https://orcid.org/0000-0002-7381-5230

Ju-mi Park https://orcid.org/0000-0003-1910-1525

\section{References}

1. Lewis S, Sharma A, Nishimura R. Treatment of edentulous maxillae with osseointegrated implants. J Prosthet Dent 1992;68:503-8.

2. Mericske-Stern R. Treatment outcomes with implantsupported overdentures: clinical considerations. J Prosthet Dent 1998;79:66-73.

3. Sadowsky SJ. The implant-supported prosthesis for the edentulous arch: design considerations. J Prosthet Dent 1997;78:28-33.

4. Dhima M, Paulusova V, Lohse C, Salinas TJ, Carr AB. Practice-based evidence from 29-year outcome analysis of management of the edentulous jaw using osseointegrated dental implants. J Prosthodont 2014;23:173-81.

5. Budtz-Jörgensen E. Effects of denture-wearing habits on periodontal health of abutment teeth in patients with overdentures. J Clin Periodontol 1994;21:265-9.

6. Marcus PA, Joshi A, Jones JA, Morgano SM. Complete edentulism and denture use for elders in New England. J Prosthet Dent 1996;76:260-6.

7. Compagnoni MA, Souza RF, Marra J, Pero AC, Barbosa DB. Relationship between Candida and nocturnal denture wear: quantitative study. J Oral 
Rehabil 2007;34:600-5.

8. Starr NL. The distal extension case: an alternative restorative design for implant prosthetics. Int J Prosthodontics Restorative Dent 2001;21:61-7.

9. Chronopoulos V, Sarafianou A, Kourtis S. The use of dental implants in combination with removable partial dentures: a case report. J Esthet Restor Dent 2008;20:355-64.

10. Zitzmann NU, Marinello CP. Treatment plan for restoring the edentulous maxilla with implantsupported restorations: removable overdenture versus fixed partial denture design. J Prosthet Dent 1999;82:188-96.

11. Pellecchia M, Pellecchia R, Emtiaz S. Distal extension mandibular removable partial denture connected to an anterior fixed implant-supported prosthesis: a clinical report. J Prosthet Dent 2000;83:60712.

12. Na HJ, Kang DW, Son MK. Distal-extension removable partial denture with anterior implant prostheses: case report. J Dent Rehabil Appl Sci 2011;27:437447.

13. Nam HS, Song KY, Park JM, Oh WS. Removable partial denture assisted by implant-retained fixed prosthesis opposing implant-retained overdenture. Gen Dent 2012;60:503-7.

14. Kratochvil FJ, Caputo AA. Photoelastic analysis of pressure on teeth and bone supporting removable partial dentures. J Prosthet Dent 1974;32:52-61.

15. Duyck J, Rønold HJ, Van Oosterwyck H, Naert I, Vander Sloten J, Ellingsen JE. The influence of static and dynamic loading on marginal bone reactions around osseointegrated implants: an animal experimental study. Clin Oral Implants Res 2001;12: 207-18.

16. Drago C, Saldarriaga RL, Domagala D, Almasri R. Volumetric determination of the amount of misfit in CAD/CAM and cast implant frameworks: A multicenter laboratory study. Int J Oral Maxillofac Implants 2010;25:920-9.

17. Winter W, Mohrle S, Holst S, Karl M. Bone loading caused by different types of misfits of implantsupported fixed dental prostheses: A three-dimensional finite element analysis based on experimental results. Int J Oral Maxillofac Implants 2010;25:94752.

18. Patel D, Invest JC, Tredwin CJ, Setchell DJ, Moles DR. An analysis of the effect of a vent hole on excess cement expressed at the crown-abutment margin for cement-retained implant crowns. J Prosthodont 2009;18:54-9.

19. Daas M, Dubois G, Bonnet AS, Lipinski P, RignonBret C. A complete finite element model of a mandibular implant-retained overdenture with two implants: comparison between rigid and resilient attachment configurations. Med Eng Phys 2008;30:21825.

20. Naert I, Gizani S, Van Steenberghe D. Rigidly splinted implants in resorbed maxilla to retain a hinging overdenture: A series of clinical reports for up to 4 years. J Prosthet Dent 1998;79:156-64.

21. Zoidis P, Polyzois G. Removable dental prosthesis splint. An occlusal device for nocturnal bruxing partial denture users. J Prosthodont 2013;22:652-6. 


\section{상악의 임플란트 고정성 보철물과 후방연장 국소의치를 이용하여 수복한 10년 경과 관찰 증례}

류리 ${ }^{1}$ 전공의, 박연희 ${ }^{1}$ 전공의, 오원석 ${ }^{2}$ 임상교수, 이정진 ${ }^{1,3}$ 조교수, 박주미 ${ }^{1,3 *}$ 교수

${ }^{1}$ 전북대학교 치과대학 치과보철학교실 및 구강생체과학연구소

${ }^{2}$ 미시간대학교 치과보철학교실

${ }^{3}$ 전북대학교병원 의생명연구원

상악 무치악 환자에서 치료 방법을 결정하는데 있어 생역학적 고려사항과 함께 전치부 치아에 대한 환자의 심미적 요구 도 고려될 수 있다. 이 증례 보고는 전치부의 임플란트 고정성 보철물과 구치부의 후방 연장 가철성 국소의치로 구강 기 능이 회복된 상악 무치악 환자의 10 년 동안 임상 결과를 기술하고 있다. 상악 전방에 임플란트 고정성 보철물로 4 개의 임 플란트를 연결고정 하였으며 후방에 가공선 유지장치를 가진 가철성 국소의치가 장착되었다. 하악 무치악은 임플란트 피개의치로 수복되었다. 경과 관찰 기간 동안 고정성 보철물의 인공치아와 전장 레진의 변색, 사고로 인한 보철물 파절 이외에 임플란트 및 국소의치 관련된 기계적, 기계적 생물학적 주요 합병증은 관찰되지 않았다.

(구강회복응용과학지 2020;36(2):121-7)

주요어: 무치악; 임플란트 지지 고정성 보철물; 가철성 국소의치; 치과 임플란트; 합병증

*교신저자: 박주미

(54907)전라북도 전주시 덕진구 건지로 20 전북대학교 치의학전문대학원 치과보철학교실 및 구강생체과학연구소

Tel: 063-250-2118 | Fax: 063-250-2218 || E-mail: jmpark@jbnu.ac. kr

접수일: 2020년 4월 20일 | 수정일: 2020년 5월 7일 | 채택일: 2020년 5월 25일 